\title{
PERHENTIAN KULINER JUANDA
}

\author{
Natasha $^{1)}$, Andi Surya Kurnia ${ }^{2)}$ \\ 1)Program Studi S1 Arsitektur, Fakultas Teknik, Universitas Tarumanagara, natashanata13@gmail.com \\ 2)Program Studi S1 Arsitektur, Fakultas Teknik, Universitas Tarumanagara, andik@ft.untar.ac.id
}

Masuk: 13-07-2020, revisi: 28-07-2020, diterima untuk diterbitkan: 24-09-2020

\begin{abstract}
Abstrak
Kelurahan Kebon Kelapa berada di Kecamatan Gambir, Jakarta Pusat, yaitu kawasan jantung ibukota yang didominasi perkantoran dan komersial. Para warga selain bekerja sebagai karyawan juga banyak yang membuka usaha di bidang kuliner sebagai pendukung kegiatan sekitar. Stasiun Juanda menjadi katalis pergerakan antara tempat pertama dan tempat kedua pada kawasan tersebut. Letak tapak yang memanjang, langsung menghadap stasiun dan menembus ke permukiman dapat menangkap arus komuter dan miningkatkan exposure usaha kuliner warga Kebon Kelapa. Peluang tempat ketiga (third place) sebagai ruang singgah netral untuk berkumpulnya para subjek pada kawasan tersebut menjadi titik temu antara warga sekitar dengan komuter stasiun. Melalui metode Narrative Architecture (Tshchumi, 1994), Perhentian Kuliner Juanda mengangkat bahan makanan serta siklusnya mulai dari produksi, distribusi, pematangan, konsumsi, hingga penguraian menjadi kegiatan pemersatu dan berkumpulnya masyarakat sekitar dengan para pekerja komuter yang berlalu-lalang setiap harinya. Kemudian proyek juga dilengkapi fasilitas pendukung seperti transit hub dan playground sebagai jembatan antar pengunjung, sehingga memungkinkan permeabilitas dari kedua sisi tapak. Di kala Kota Jakarta mengalami proses di mana ruang dan waktu berjalan sendiri-sendiri, manusia tidak lagi mengalami ruang akibat tuntutan mobilitas tinggi. Kota menjadi sekedar tempat bertahan hidup (Armand, 2017). Dengan menghadirkan pengalaman dan perasaan baru terhadap ruang melalui pangan sebagai kebutuhan primer sehari-hari menghubungkan potensi lokal dengan pendatang, Perhentian Kuliner Juanda menjadi dapur dan ruang makan kota di tengah kesibukan urban.
\end{abstract}

\section{Kata kunci: komuter; pangan; stasiun; warga}

\begin{abstract}
Kebon Kelapa sub-district is located in Gambir, Central Jakarta. It is a capital region dominated by offices and commercial buildings. The people there are working as employees and many residents also open small culinary businesses to support surrounding activities. Juanda Station is a catalyst for mobility between the first place and the second place in that area. The location of the site that extends directly facing the station towards neighborhood allow to collect the flow of commuters and provide an opportunity for more exposure to the culinary businesses by the local community of Kebon Kelapa. The chance for a third place as a neutral transit space to gather people in the area. It becomes a meeting point between local community and the station commuters. Through Narrative Architecture (Tshchumi, 1994), Juanda Food Station promote food ingredients and the cycles from production, distribution, cooking process, consumption, and decomposition as unifying activities for the local community and commuter workers passing by every day. The project is also equipped with supporting facilities such as transit hub and playground as bridges between the characters of visitors, allowing permeability from both sides of the site. When the city experiences a process where space and time run independently, humans are no longer experience space due to the demands of high mobility. Cities become merely a place of survival (Armand, 2017). By presenting new space experiences through food as daily primary needs connecting local potential with newcomers, Juanda Food Station becomes an urban kitchen and dining in the middle of the city rush.
\end{abstract}

\section{Keywords: commuters; food; local community; station}




\section{PENDAHULUAN}

\section{Latar Belakang}

Jakarta sebagai kota metropolitan, ibu kota negara Indonesia, dengan kepadatan mencapai 10.846.145, yang mana melebihi tiga kali lipat selama 4 dekade terakhir. Kota yang heterogen dengan tuntutan mobilitas tinggi mengakibatkan orang-orang sibuk dengan kepentingannya masing-masing. Setiap harinya masyarakat mengawali hari dengan bekerja kemudian menutup hari dengan beristirahat dan berkumpul bersama keluarga. Hal ini telah menjadi siklus yang terus menerus hingga akhirnya kehidupan sosial dalam lingkungan terkikis bahkan terabaikan. Oldenburg (1989) mengatakan bahwa untuk mencapai kehidupan yang utuh diperlukan keseimbangan antara tiga unsur, yaitu domestik, produktivitas, dan sosial inklusif. Dengan pemahaman demikian kemudian muncul istilah bagi wadah untuk memenuhi kebutuhan tersebut, yaitu First Place, Second Place, dan Third Place. First Place mengacu kepada kebutuhan domestik (home - bentuk residensial, tempat tinggal, unit sosial yang terbentuk dari keluarga yang hidup bersama), Second Place sebagai tempat melakukan produktivitas (workplace - tempat bekerja maupun beraktivitas), sementara Third Place hadir sebagai tempat sosial pemisah sekaligus jembatan di antara mereka.

Berdasarkan riset The 2017 Global Least \& Most Stressful Cities Ranking, Jakarta menempati posisi ke 132 dari 150 yang berarti merupakan salah satu kota dengan tingkat stress tinggi. Hal ini disebabkan oleh kualitas kota yang kurang baik dari segi kepadatan, mobilitas, transportasi umum, hingga berbagai polusi. Selain itu Jakarta juga masuk ke dalam 10 besar kota dengan jam kerja terburuk di dunia yaitu 40,4 jam per minggu. Data tersebut mengindikasikan Jakarta sebagai kota yang memiliki tuntutan dalam tekanan tinggi khususnya bagi pekerja.

Jakarta mengalami proses di mana ruang dan waktu berjalan sendiri-sendiri, tidak saling mengisi. Kota menjadi sekedar tempat bertahan hidup, bukan tempat hidup yang mampu memberi arti keberadaan kepada penghuni (Armand, 2017). Di pusat-pusat kota, bangunanbangunan tidak lagi saling melengkapi melainkan saling bersaing. Jakarta Pusat dengan fokus pengembangan pusat pemerintahan, perkantoran, perdagangan dan jasa mengisi hampir $50 \%$ dari keseluruhan wilayahnya, sementara permukiman semakin tergeser ke pinggir kota. Menjawab kebutuhan mobilitas tinggi pemprov DKI Jakarta melakukan pembangunan dengan orientasi transit berbasis transportasi massal (Transit Oriented Development (TOD)).

Sarana dan prasarana transportasi massal telah menjadi perantara sekaligus katalis masyarakat urban dalam mencapai tujuan destinasi setiap harinya. Hal ini secara tidak langsung menciptakan ruang pertemuan bagi masyarakat dari berbagai sudut kota. Maka terbentuk peluang bagi arsitektur untuk menciptakan ruang interaksi sebagai tanggapan dari kesibukan penghuni kota, dimana masyarakat dapat singgah dan berhenti sejenak untuk menikmati pengalaman hidup di kota yang selama ini tereduksi akibat diburu waktu.

"In order to design buildings with a sensuous connection to life, one must think in a way that goes far beyond form and construction."

- Peter Zumthor, 1998, Thinking Architecture

Kelurahan Kebon Kelapa merupakan salah satu kawasan strategis Jakarta yang didukung dengan berbagai moda transportasi. Kawasan ini berada di tengah Kawasan TOD Harmoni dan Juanda, Kecamatan Gambir, Jakarta Pusat. Halte Transjakarta Harmoni Sentral merupakan halte tersibuk di Jakarta Pusat yang melayani 10 koridor juga dilewati 25 rute perjalanan. Harmoni direncanakan untuk dikembangkan menjadi kawasan TOD dan dijadwalkan pembangunan MRT pada fase kedua dengan target penyelesaian di tahun 2024. Kawasan yang berada di jantung ibukota ini juga didukung dengan commuter line di Stasiun Juanda sebagai unit pelayanan Bogor dan Bekasi. Kelurahan Kebon Kelapa didominasi oleh fungsi perkantoran 
yang menyebabkan tingginya arus komuter pekerja yang tinggal di luar kelurahan. Berada di kawasan strategis di tengah Pasar Baru, Hayam Wuruk dan Mangga Besar mendorong munculnya usaha kuliner untuk memenuhi kebutuhan konsumsi seperti di Jalan Pecenongan. Selain itu juga banyak PKL dan UKM makanan di sekitar jalan kelurahan. Menjamurnya warung dan rumah makan pada kawasan mengakibatkan tingginya kebutuhan akan bahan mentah yang masuk ke dalam kelurahan kebon kelapa. Sementara pasar terdekat berupa pasar tumpah yang berada di Gang Ceylon, yang tidak memiliki bangunan permanen.

"It is not organized in the name of functionalism but by place-making that encourages people to seek a spectrum of opportunities."

- Sou Fujimoto, 2008, Primitive Future Menanggapi fenomena tersebut muncul kesempatan untuk dapat menyediakan pangan berupa bahan mentah juga olahan makanan dengan upaya produksi yang dilakukan secara mandiri untuk memenuhi kebutuhan lokal warga sekitar serta usaha kuliner dalam kelurahan sehingga dapat mengurangi biaya serta energi untuk distribusi dari produsen menuju konsumen. Hal ini ditujukan untuk menerapkan sistem produksi dan konsumsi berkelanjutan dan membantu menjaga keseimbangan ekosistem. Simbiosis mutualisme dengan mengangkat potensi lokal dan kebutuhan visitor menghadirkan ruang singgah berbasis pangan atau kuliner yang menawarkan pengalaman pengolahan dari produksi - distribusi - konsumsi - kompos dalam satu titik, menciptakan suasana baru dalam proses konsumsi makan sehari-hari. Akses kawasan TOD memberi kesempatan exposure lebih luas bagi masyarakat di luar kawasan untuk mengenali potensi Kelurahan Kebon Kelapa.

Zumthor mengatakan bahwa arsitektur bukan sekedar wadah namun bagaimana arsitektur menciptakan kesempatan interaksi antar manusia juga program di dalamnya dengan pengalaman dan perasaan dalam menghargai hidup. Maka muncul gagasan Third place yang hadir sebagai pemutus rutinitas robotik antara home dan workplace. Mengangkat potensi dan kebutuhan kawasan Kelurahan Kebon Kelapa untuk memberdayakan lokalitas sebagai ruang interaksi antar warga juga dengan pengunjung (pekerja komuter). Ruang singgah untuk melepas kepenatan, istirahat sejenak untuk memaknai hidup melalui pengalaman ruang.

\section{Rumusan Permasalahan}

Berdasarkan latar belakang tersebut dapat disimpulkan bahwa kota Jakarta dengan tingginya arus mobilitas khususnya para pekerja komuter Stasiun Juanda menggambarkan kehidupan kota yang diburu waktu dan tidak lagi mengalami ruang (Armand, 2017). Sementara warga Kelurahan Kebon Kelapa memiliki potensi usaha kuliner yang dapat menjadi interaksi dan pertemuan antara warga lokal dengan pendatang (pekerja komuter) di kawasan tersebut. Dengan posisi tapak yang langsung menghadap Stasiun Juanda, maka usulan Third Place sebagai ruang netral dapat menjembatani rutinitas warga kota dari first place dan second place juga peluang bagi usaha kuliner lokal.

\section{Tujuan}

Perancangan third place tersebut berperan sebagai ruang singgah dan interaksi bagi warga Kebon Kelapa dengan komuter Stasiun Juanda, memberikan kesempatan para pengunjung untuk terhubung kembali dengan makanan melalui pengalaman ruang. Proyek juga dilengkapi fasilitas pendukung bagi pengunjung sehingga memungkinkan permeabilitas menembus tapak baik dari stasiun maupun permukiman. Tujuan penulisan jurnal sendiri sebagai kontribusi bagi ilmu pengetahuan arsitektur khususnya tentang keberadaan third place yang tanggap tapak (respond to site). Selain itu diharapkan dapat mendorong pemerintah daerah dan pemerhati kota dalam meningkatkan kualitas perencanaan kota. 


\section{KAJIAN LITERATUR}

\section{Third Place}

Dalam konteks urban Third Place berperan sebagai ruang publik bagi warga yang heterogen. Third place berfokus pada kehidupan dan interaksi sosial yang inklusif secara informal tanpa adanya keterikatan (semua orang tanpa membeda-bedakan) seperti pertokoan, kedai kopi, perpustakaan publik, hingga tempat ibadah. Karakteristik Third Place dikemukakan Oldenburg (1989) meliputi: ${ }^{1}$

a. On Neutral Ground - Merupakan zona netral yang terbuka bagi berbagai kemungkinan sehingga mengundang orang untuk datang dan berkumpul sesuai kebutuhan masingmasing.

b. The Third Place as Leveler (media penyamarataan)- Third Place sebagai tempat inklusif dimana orang dapat berkumpul tanpa alasan untuk mengekspresikan kesenangan dan kepribadian tanpa memandang kelas maupun tujuan.

c. Conversation is the Main Activity - Zona netral menyediakan tempat dan leveling memberikan kesempatan interaksi bagi aktivitas yang berkelanjutan yaitu percakapan.

d. Accessibility and Accommodation - Third Place sebagai dapat diakses secara bebas dan terbuka bagi siapa saja.

e. The Regulars - Pengunjung rutin menciptakan karakteristik tertentu dalam suatu kawasan selain itu juga menarik pengunjung baru.

f. A Low Profile -Karakter sederhana yang menerima setiap individu

g. The Mood is Playful - Suasana yang ceria, saling menghargai, tanpa tekanan maupun perselisihan

h. A Home Away from Home - Serupa dengan rumah yang memberikan kenyamanan dan dukungan psikologis yang lebih luas.

\section{Arsitektur Sebagai Respon}

Intentions in Architecture

Norberg (1968) mengemukakan 4 konsep sebagai tanggapan arsitektur sebagai bangunan dan wadah aktivitas, yaitu filter, connector, barrier, dan switch. ${ }^{2}$

a. Filter-membuat koneksi secara tidak langsung (terkontrol)

b. Barrier-memisahkan antar elemen

c. Connector - menciptakan hubungan langsung secara fisik

d. Switch - sebagai regulasi dari connector

\section{Placemaking}

Placemaking menciptakan kembali ruang publik sebagai jantung kegiatan warga. Placemaking memperkuat hubungan antar individu dengan tempat yang digunakan bersama, merujuk pada proses kolaboratif dalam rangka memaksimalkan nilai-nilai kebersamaan. Lebih dari sekedar mempromosikan perancangan kota yang lebih baik, placemaking memfasilitasi penggunaan kreatif yang berfokus pada identitas fisik, budaya dan sosial yang mendefinisikan sebuah tempat dan mendukung perkembangan yang sedang berlangsung. ${ }^{3}$

\section{Ketahanan Pangan}

Ketahanan pangan adalah ketersediaan pangan dan kemampuan seseorang untuk mengaksesnya. Ketersediaan pangan berhubungan dengan suplai pangan melalui produksi, distribusi, dan pertukaran. Berdasarkan Sustainable Development Goals 2030, pertanian urban merupakan upaya dalam mewujudkan :

\footnotetext{
${ }^{1}$ Oldenburg, Ray. 1989. The Great Good Place. HIm 22.

${ }^{2}$ Norberg-Schulz, Christian. 1968. Intentions in Architecture.

3 Project for Public Spaces. www.pps.org (20/1/2020)
} 
No. 2. Menghentikan kelaparan, mencapai ketahanan pangan dan meningkatkan nutrisi serte mempromosikan agrikultur berkelanjutan.

No. 3. Memastikan kehidupan yang sehat dan mempromosikan well-being (kesehatan fisik dan mental) bagi segala usia.

No. 11. Menciptakan kota dan permukiman manusia yang inklusif, aman, resilien, dan berkelanjutan.

No. 12. Memastikan keberlanjutan antara pola konsumsi dan produksi

\section{Transport Hub (Fasilitas Transit)}

Transport Hub disebut juga Transport Interchange adalah tempat dimana penumpang dapat melakukan pergantian kendaraan antar moda transportasi. Transportasi publik meliputi stasiun kereta, stasiun rapid transit, halte bus, halte tram, bandara, dan pelabuhan. Suatu potongan atau bagian dari jalan kota yang berfungsi sebagai Transit Hub disebut juga Transit Mall. Transit Mall hadir akibat kebutuhan masyarakat untuk memiliki area yang tidak didominasi oleh kendaraan bermotor supaya perjalanan lebih cepat dengan kendaraan transit sebagai transportasi utama.

\section{Playground (Taman Bermain)}

Playground, playpark, play area atau taman bermain merupakan tempat yang dirancang ramah anak untuk dapat bermain dengan leluasa. Taman bermain juga bisa memiliki fasilitas bermain informal seperti olahraga dewasa. Biasanya taman bermain publik merupakan bagian dari sekolah, fasilitas kesehatan anak, permukiman, maupun area rekreasi. Perancangan dipengaruhi tujuan juga target pengguna seperti pemisahan area bermain, ketersediaan fasilitas, hingga material dan ergonomi.

\section{METODE}

\section{Metode Penelitian (Pengumpulan Data)}

a. Studi Literatur (Kepustakaan)

Studi dari berbagai buku, dokumentasi, dan publikasi seperti Badan Pusat Statistik yang dilakukan untuk memperoleh fakta, data, serta teori yang mendukung pemahaman Third Place sebagai dasar pemikiran untuk memperoleh solusi yang dapat dipertanggungjawabkan.

b. Observasi Lapangan (Pengamatan)

Tinjauan langsung pada kawasan Kelurahan Kebon Kelapa untuk merasakan secara nyata keadaan serta mendokumentasikan kegiatan dan fenomena yang terjadi di lapangan.

c. Wawancara dan Diskusi (Interaksi)

Interaksi dengan warga sebagai subjek yang berkegiatan di kawasan Kelurahan Kebon Kelapa sebagai peluang interaksi dua arah terhadap kebutuhan maupun keresahan yang dialami disana. Metode ini juga dilakukan sebagai indikator kevalidan data yang sebelumnya diperoleh melalui studi literatur.

\section{Metode Perancangan}

a. Responses to Site (Tanggap Tapak)

Metode tersebut dibagi menjadi dua, yaitu Regionalism dan Contextualism (Jormakka, 2008) Pada perancangan ini diterapkan Contextualism sebagai respon terhadap tapak yang diperoleh dari proses penggambaran serta penjabaran diagram terhadap morfologi lingkungan. Hal tersebut ditujukan untuk merekonstruksi ulang dengan komposisi baru yang mengaplikasikan karakteristik lokal.

b. Narrative Architecture (Arsitektur Naratif)

Suatu transformasi dari proses atau tahapan yang diolah menjadi hasil. Sebuah narasi tidak hanya menggambarkan suatu tahapan namun juga sebuah bahasa (Tschumi, 1994). 
Menganalisa arsitektur secara 'frame by frame', per tahap seperti mesin penyunting film. Dimana alur yang ada diterjemahkan menjadi keseluruhan suatu tatanan yang kemudian saling dikaitkan untuk mencapai kesimpulan terbuka sebagai bekal transformasi ruang. Beberapa strategi dalam pengolahan yaitu repetition, disjunction, distortion, dissolution, insertion, dan juxtaposition.

\section{DISKUSI DAN HASIL}

\section{Kawasan dan Tapak}

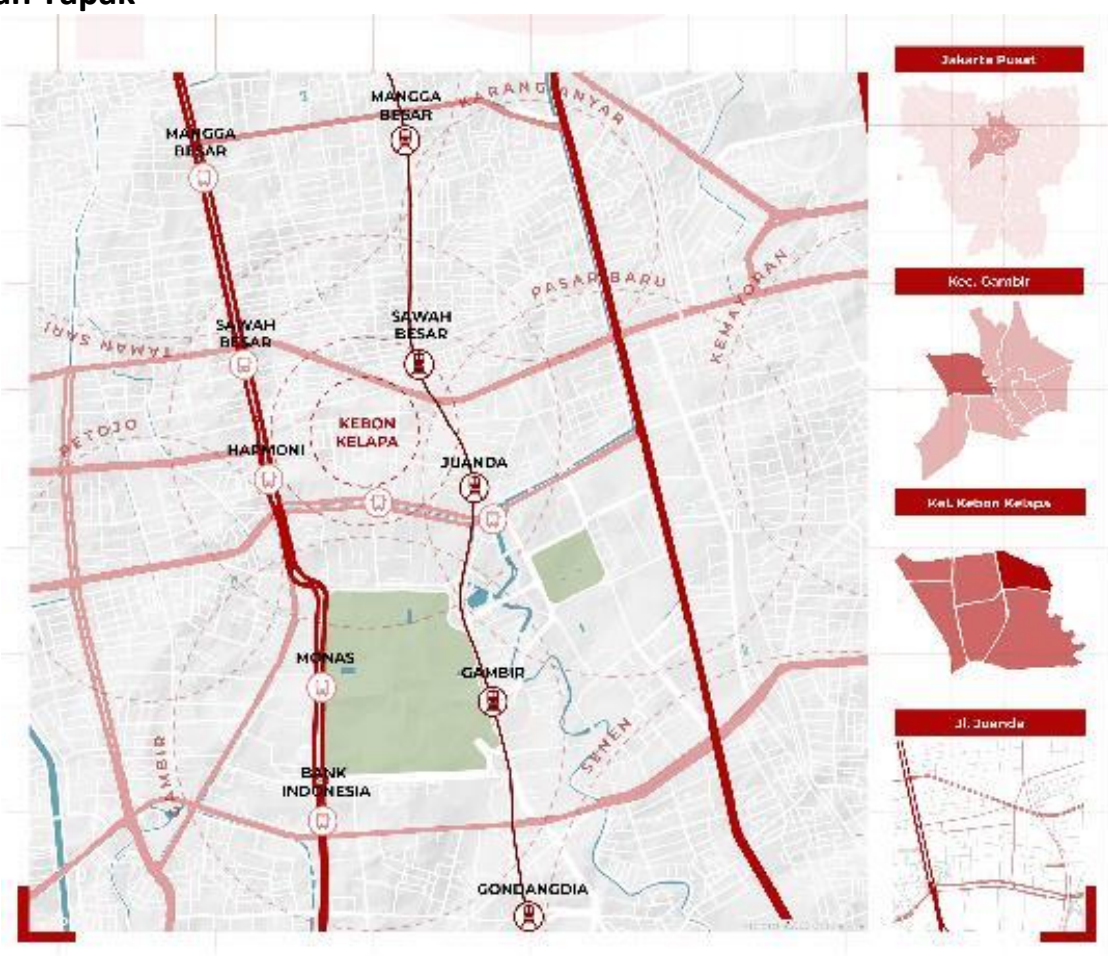

Gambar 1. Kel. Kebon Kelapa dan sekitar Sumber: Penulis, 2020

Jakarta Pusat menjadi simpul konsentrasi Second Place sekaligus kawasan dan jalur strategis yang dilewati para pekerja dari dan menuju tempat bekerja sehari-hari. Kelurahan Kebon Kelapa adalah salah satu kawasan pengembangan TOD Harmoni dan Juanda. Stasiun KRL Juanda melayani commuter line Bogor dan Bekasi.

Pemetaan rumah makan, warung, kedai, UKM bidang kuliner yang berada di Kelurahan Kebon Kelapa menunjukan setelah dominasi fungsi perkantoran muncul banyak usaha kuliner sebagai tanggapan untuk memenuhi kebutuhan makan sehari-hari para pekerja. Tingginya kebutuhan bahan makanan mentah tidak diimbangi dengan ketersediaan supply dari pasar tumpah di Gang Ceylon (pasar non permanen). Muncul kesempatan untuk menyediakan pangan berupa bahan mentah juga olahan makanan yang diproduksi dan diolah secara mandiri untuk meringkas proses distribusi dari luar kawasan. Pemilihan tapak dimaksudkan menjadi ruang transit bagi para pekerja dari dan menuju stasiun. Selain itu letaknya dilewati akses antara permukiman dengan stasiun, memungkinkan program bagi pelayanan lingkungan. 


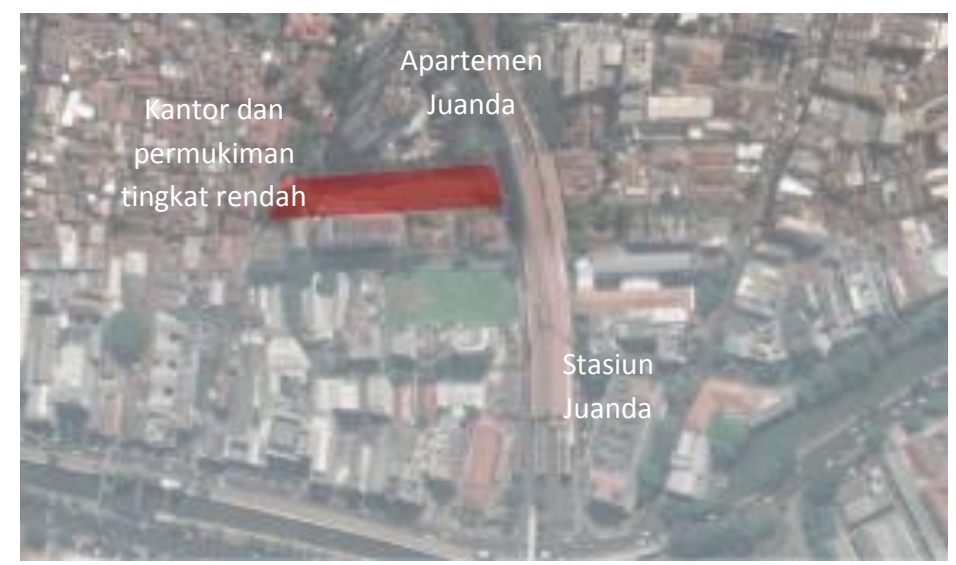

Gambar 2. Tapak dan sekitarnya (mikro)

Sumber: Penulis, 2020

Tapak terpilih berpotensi sebagai passage atau path alternatif bagi para pedestrian dari dan menuju ke stasiun Juanda. Bentuk tapak yang memanjang dapat menjadi connector antara permukiman dan stasiun (Intentions in Architecture, Norberg 1968). Menerapkan konsep transit mall sebagai area khusus pedestrian yang menutup akses bagi kendaraan bermotor. Sehingga pengunjung dapat berjalan kaki dengan aman dan nyaman serta melalui program yang ditawarkan dalam proyek.

\section{Program}

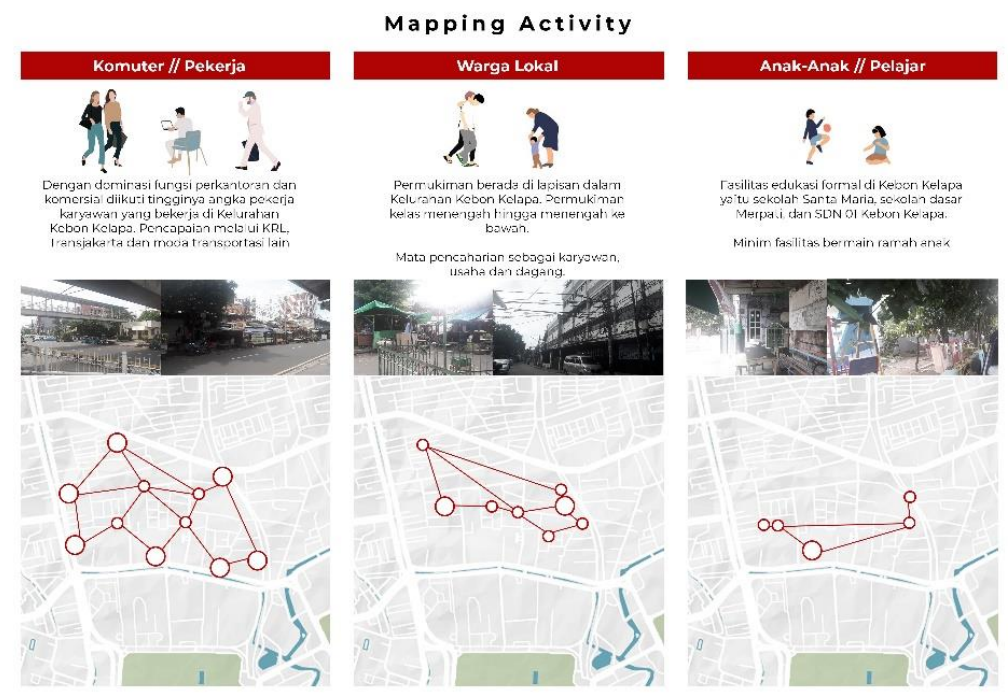

Gambar 3. Pemetaan aktivitas warga lokal dan komuter Sumber: Penulis, 2020

Penelusuran terhadap Kelurahan Kebon Kelapa menghasilkan pola berpikir yang dapat dijabarkan dari fenomena keseharian kelurahan oleh komuter (pendatang) dan warga lokal (residen), kemudian investigasi isu didukung literatur bahwa warga kota tidak lagi mengalami ruang dalam menjalankan aktivitasnya akibat diburu waktu. (Armand, 2017) Selanjutnya dengan metode placemaking merujuk pada kepekaan akan kebutuhan program yang provokatif dalam suatu kawasan untuk menciptakan berbagai peluang dalam memanfaatkan suatu tapak. (Fujimoto, 2008) Akhirnya diterjemahkan ke dalam program yang akan diajukan yang berfokus kepada Culinary, Transit Hub, dan Playground sebagai third place yang ditujukan bagi pelaku yang berkeseharian di Kelurahan Kebon Kelapa. 


\section{Culinary (Pusat Kuliner)}

Pusat kuliner dilengkapi dengan fasilitas produksi sayuran pada community garden, distribusi pada pasar, hingga pengolahan bahan makanan mentah menjadi makanan siap santap. Melalui community garden, kebun milik bersama, mendorong warga untuk dapat aktif berperan dalam mewujudkan pola produksi dan konsumsi berkelanjutan. Selain itu juga menjadi penyaluran hobi dan melahirkan komunitas tertentu yang bertujuan mempererat interaksi antar warga. Sementara Pasar menjadi tempat interaksi sosial yang erat dalam masyarakat. Memberikan pengalaman baru dalam menikmati konsumsi sehari-hari melalui penciuman, sentuhan, dan rasa (to smell, to touch, to taste). Proyek merangkum keseluruhan siklus yang utuh dari bahan sayur segar hingga diproses menjadi makanan yang ada di piring para konsumen. Melalui produksi lokal juga mengangkat kuliner nusantara yang menjadi highlight dari menu yang disajikan.

\section{Transit Hub (Fasilitas Transit)}

Dengan posisi tapak yang berhadapan dengan pintu samping Stasiun Juanda, maka program yang diajukan berupa ruang transit yang menjadi penghubung antara permukiman dengan stasiun. Dilengkapi dengan fasilitas edukasi dan rekreasional sebagai daya tarik pelepas penat.

\section{Playground (Taman Bermain)}

Playground yang dimaksud menjadi ruang bermain bagi segala usia sebagai tanggapan tapak yang berada dekat dengan permukiman dengan fasilitas minim bagi anak. Playground berperan sebagai program pelebur tapak ke bangunan, masyarakat sekitar dengan pengunjung, tidak hanya dinikmati anak-anak namun juga orang dewasa.

\section{Transformasi Massa}

Narrative Architecture

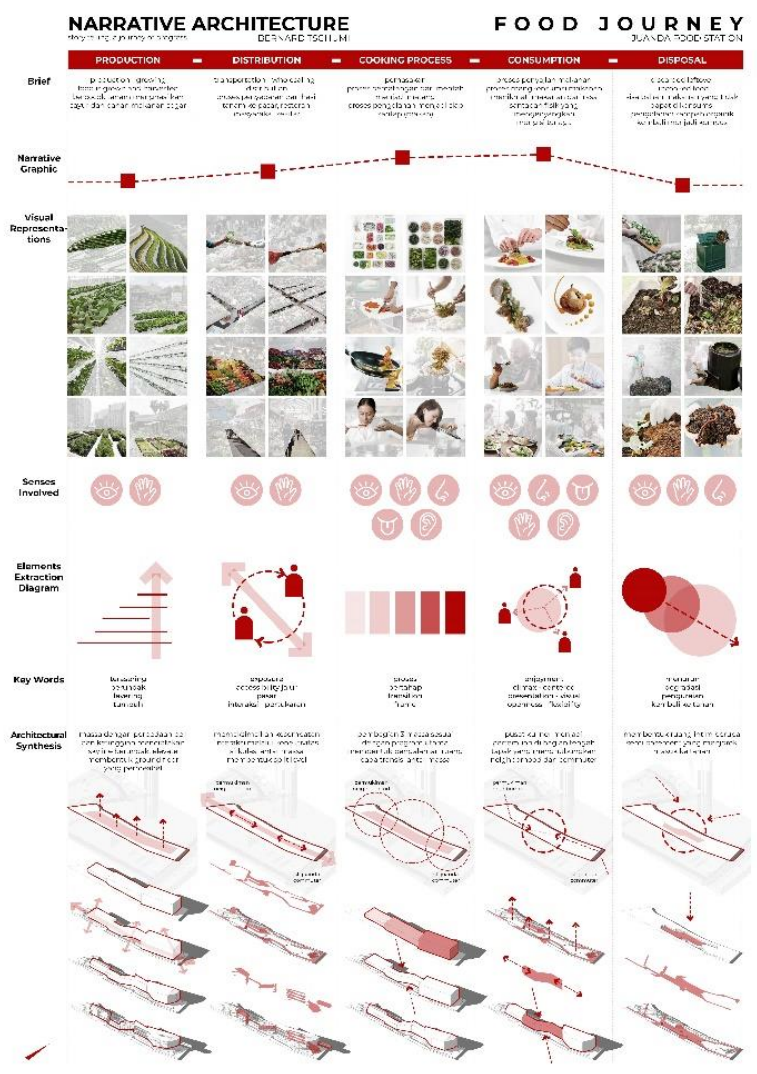

Gambar 4. Skema proses transformasi massa berdasarkan Narrative Architecture Sumber: Penulis, 2020 
Proses transformasi utama dioleh berdasarkan Narrative Architecture (Tschumi, 1994) dari perjalanan makanan yaitu produksi, distribusi, pematangan, konsumsi, dan penguraian. Gambar-gambar berikut merupa-kan representasi visual dengan highlight untuk mengambil kesimpulan dari masing-masing prosesnya. Indra yang berperan terkonsentrasi pada proses pematangan dan konsumsi.

Diagram yang terbentuk kemudian diproses menjadi sintesis arsitektur ke dalam perancangan yang menunjukan sifat-sifat dari ekstraksi elemen dan kata kunci dengan saling overlap supaya dapat saling melengkapi.

a. Massa dengan perbedaan peil dan ketinggian menciptakan skyline berundak ke arah stasiun.

b. Memaksimalkan kesempatan interaksi melalui konektivitas sirkulasi antar massa membentuk split level.

c. Pembagian 3 massa sesuai dengan program utama membentuk pengalaman ruang pada transisi antar massa.

d. Pusat kuliner menjadi pertemuan di bagian tengah tapak yang menghubungkan permukiman (neighborhood) dan komuter stasiun.

e. Membentuk ruang intim berupa semi basement yang menjorok masuk ke tanah.

Zonasi berdasarkan terget pengunjung yaitu Transit Hub pada bagian timur tapak terhubung langsung dengan stasiun juanda terdiri dari fasilitas yg ditujukan bagi komuter berupa lounge ruang istirahat, penitipan, coffeeshop, ruang olahraga, coworking space. Kemudian Playground pada bagian barat tapak yang ditujukan bagi warga kelurahan Kebon Kelapa, dilengkapi dengan lapangan dan area bermain, ruang edukasi interaktif, open library, rooftop garden. Bagian tengah tapak menjadi pertemuan antara kedua target pengunjung pada Food Station yg terbagi menjadi area makan, food market, dapur bersama, pasar, community garden, menghadirkan pengalaman ruang dari perjalanan makanan, menjadi program yang memicu interaksi antar pengunjung.

\section{Respond to Site (Contextualism)}

Sebagai bangunan yang terhubung langsung dengan Stasiun Juanda, maka pengolahannya menyelaraskan elemen yang ada pada stasiun. Berdasarkan studi tipologi dari Stasiun Juanda, karakter bangunan memanjang dengan skylight dan atap miring teritis. Kemudian menggambarkan pergerakan dan sirkulasi antar lantai. Pada fasad terdapat repetisi ritme pola dengan kisi vertikal. Sehingga hasil aplikasi ke dalam proyek yaitu:
a. Memaksimalkan sinar matahari (skylight atap miring)
b. Ritme menonjolkan sumbu vertikal
c. Konektivitas antar massa dengan peil tangga dan ram
d. Bangunan memanjang, ground floor permeabel 


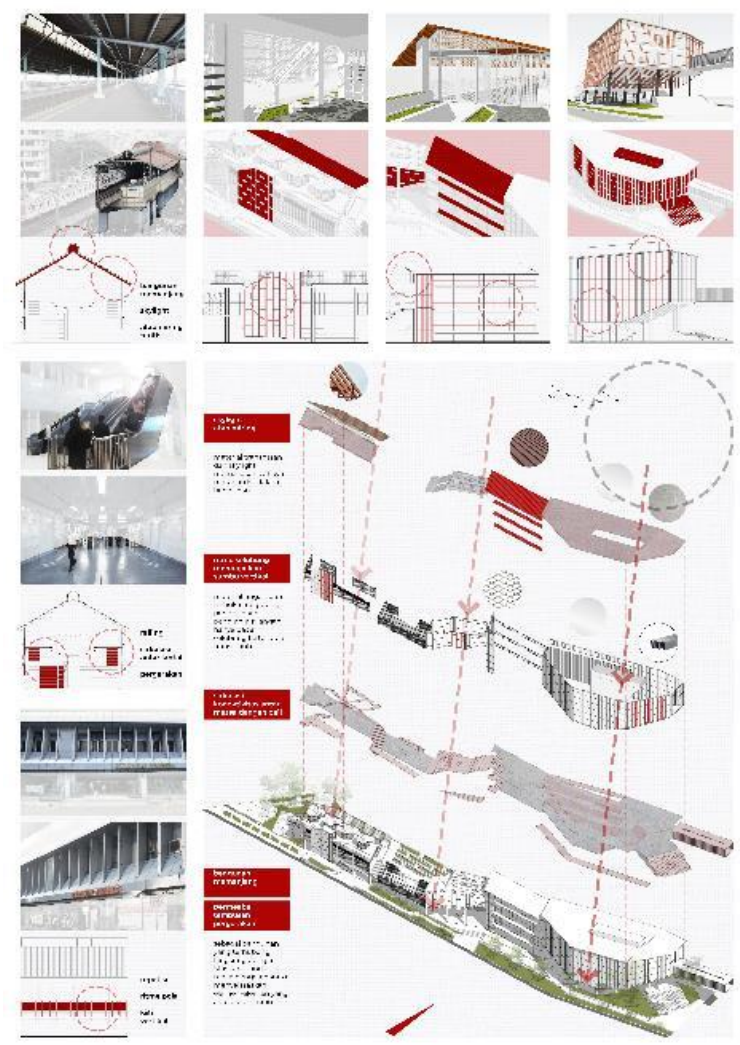

Gambar 5. Skema pengolahan fasad berdasarkan Respond to Site (Contextualism) Sumber: Penulis, 2020

Pada lantai dasar dengan opening lebar menyambut komuter dari arah stasiun, terhubung ke area makan di semi basement dan playground ke belakang. Lantai 1 merupakan lobby dan lounge, terhubung ke food market. Pada bagian belakang untuk area pembibitan dan edukasi. Lantai 2 terkoneksi langsung dengan stasiun melalui jembatan penyeberangan, menghubungkan lounge, gym, food market, dan ruang serbaguna. Lantai 3 untuk coworking, food market, dan rooftop garden.

Dari potongan dan tampak bangunan yang memanjang terlihat skyline berundak ke arah stasiun. Kemudian hubungan antar massa dengan ram dan tangga. Area makan, ruang sebaguna, rooftop garden dan ruang-ruang lainnya memiliki kualitas ruang berbeda dan menarik sehingga memberi kesan playful. Pada area penanaman vertikal menjadi dinding interaktif pada open library. Sementara pasar menjadi wadah distribusi dari hasil bercocok tanam.

\section{Makanan dan Third Place}

Berdasarkan sejarah makanan dari masa ke masa, makanan pada awalnya merupakan kebutuhan fisik. Selanjutnya berkembang menjadi komoditas yang mengumpulkan orang dan mendorong inovasi. Hingga akhirnya dengan segala prosesnnya yang instan, 'we lost contact with food'. Kesimpulan akhir yaitu:
a. cooking civilized us
b. people bond over food
c. menciptakan new connection with food
d. people can take their time to appreciate food and enjoy moments. 


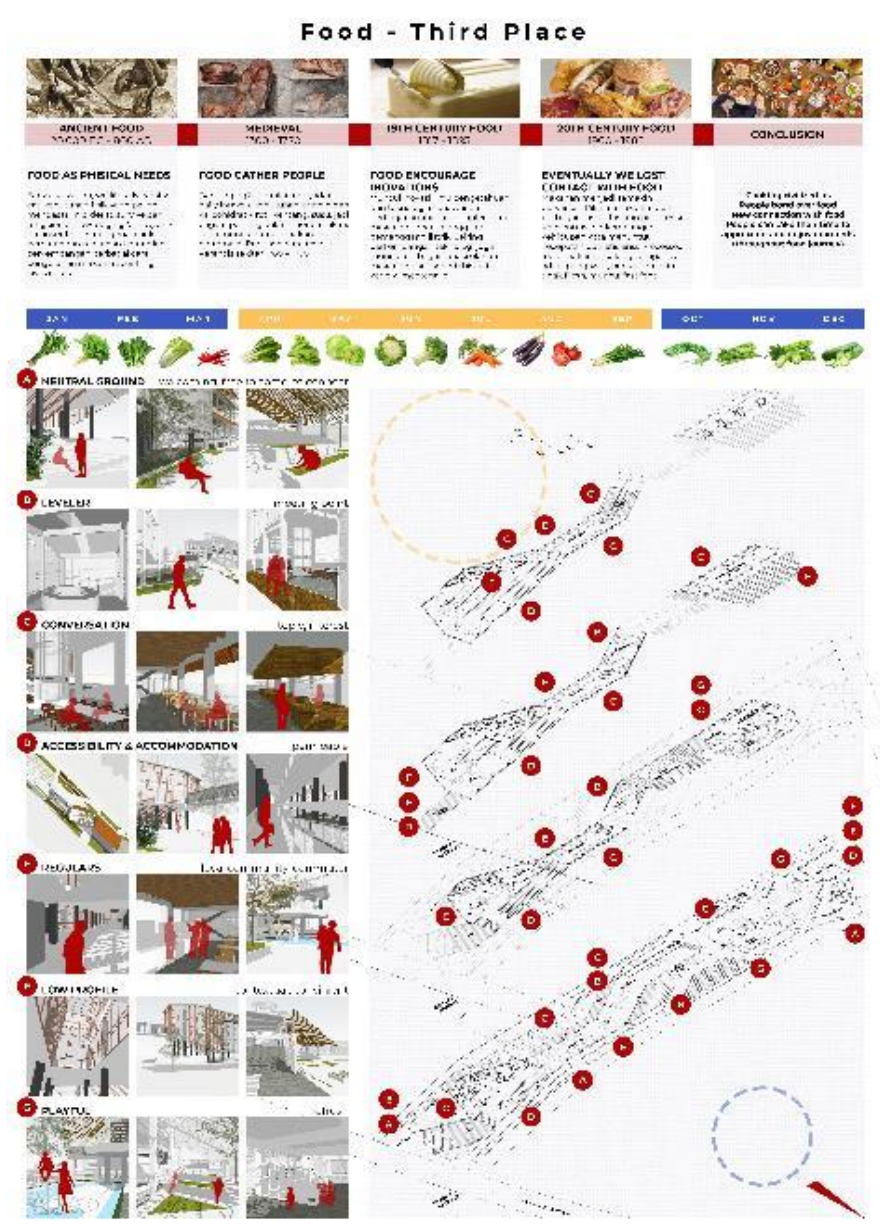

Gambar 6. Diagram Third Place pada proyek

Sumber: Penulis, 2020

Penguraian karakteristik third place dalam proyek

a. Neutral ground - welcoming, tidak mengikat, ruang singgah

b. Leveller - pertemuan antara berbagai karakter pengunjung

c. Conversation - interaksi, mengobrol

d. Accessibility \& accomodation - permeabel, memungkinkan entrance dari beberapa sisi, juga tembusan antar massa

e. Regulars - warga lokal dan komuter

f. Low profile - kontekstual dari karakteristik Stasiun Juanda

g. Playful - suasana menyenangkan untuk me-refresh dari kehidupan perkotaan

\section{Siklus Makanan}

Dengan menghadirkan pengalaman dan perasaan baru terhadap pangan mulai dari farming, belanja fresh ingredients, cooking course, dapur bersama, hingga penyajian makanan, Perhentian Kuliner Juanda (Juanda Food Station) menjadi urban kitchen and dining ditengah kesibukan kota.

a. Proses makanan dari penanaman di community garden dilengkapi ruang pembelajaran interaktif mengenai cara berkebun bagi pengunjung

b. Distribusi sayuran segar di pasar bagi warga sekitar juga untuk food market

c. Pengolahan makanan hingga siap saji pada food market juga dapur bersama menawarkan pengalaman dan interaksi

d. Konsumsi untuk menikmati makanan bersama, menjadi urban kitchen and dining

e. Penguraian sisa makanan menjadi kompos untuk pupuk tanaman 


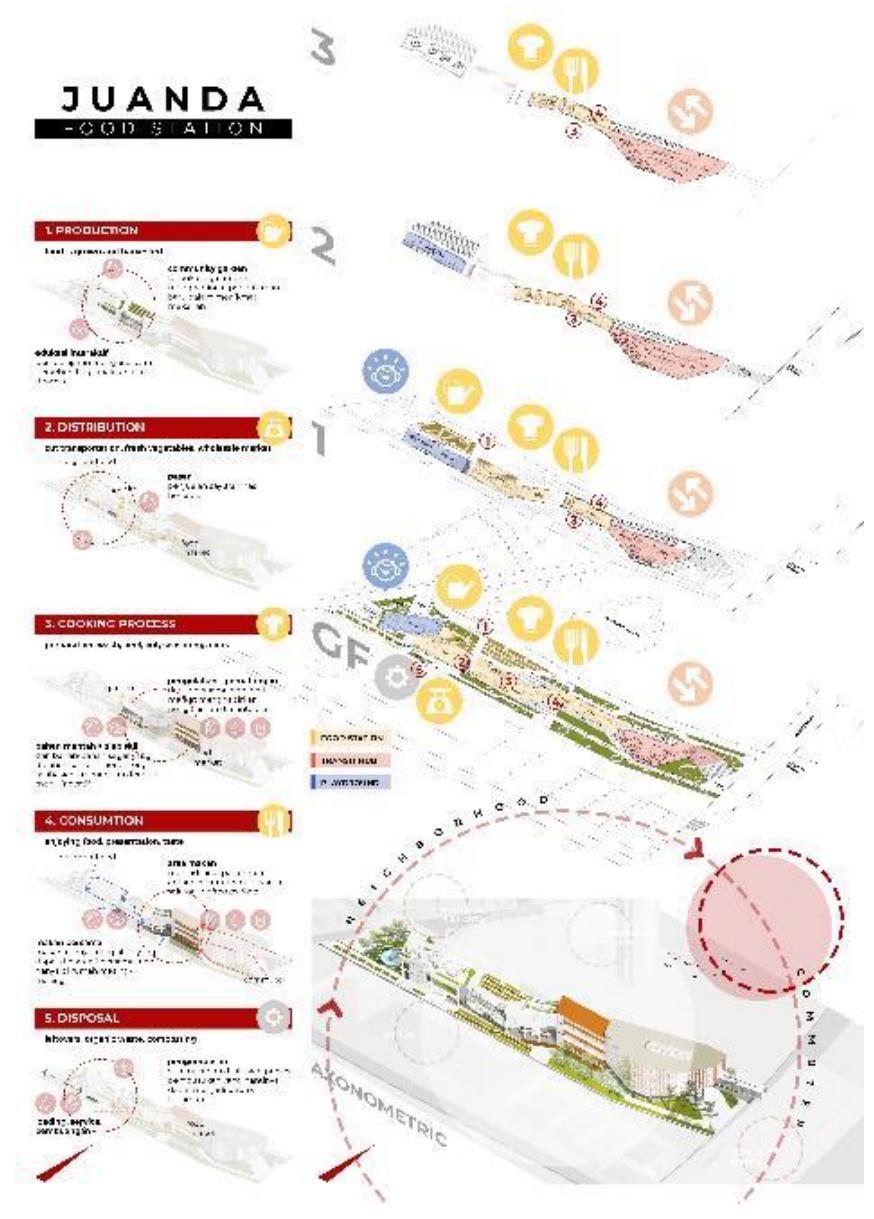

Gambar 7. Zonasi Program dan Siklus Makanan

Sumber: Penulis, 2020

\section{Sistem Bangunan}

\section{Elemen Bangunan}

a. Pengolahan tapak dengan lekukan yang menjorok ke tengah tapak yang menciptakan alur pergerakan permeabel ke dalam bangunan.

b. Struktur penopang dengan kolom beton berukuran $40 \times 40 \mathrm{~cm}^{2}$, dan balok beton ukuran $25 \times 55 \mathrm{~cm}^{2}$.

c. Penampang lantai tingkat yang breathable tidak masif, alokasi program juga dilakukan pada lantai dasar, media sirkulasi dan atap.

d. Penghubung antar peil melalui tangga dan ram yang diolah interaktif di tiap massa sehingga berperan aktif dalam mewadahi kegiatan.

e. Selubung penutup pembentuk massa dan ruang selaras dengan ritme fasad Stasiun Juanda sebagai upaya kontekstual lingkugnan. Material dengan rangka aluminium $4 \times 15 \mathrm{~cm}^{2}$, tempered glass, dan aluminium mesh.

f. Area penanamaan dan produksi sayuran secara vertikal dan horisontal juga berperan sebagai selubung pada massa bagian barat.

g. Penutup atap transit hub dengan dak beton dan skylight supaya matahari dapat masuk ke tengah bangunan. Area pusat kuliner memodifikasi atap pelana membentuk kemiringan dan teritis. Area playground membentuk rooftop garden dan atap miring untuk kesan terbuka pada area penanaman. Corong penangkap air hujan mengalirkan air hujan ke Ground Water Tank untuk penyiraman tanaman dan air daur ulang. 


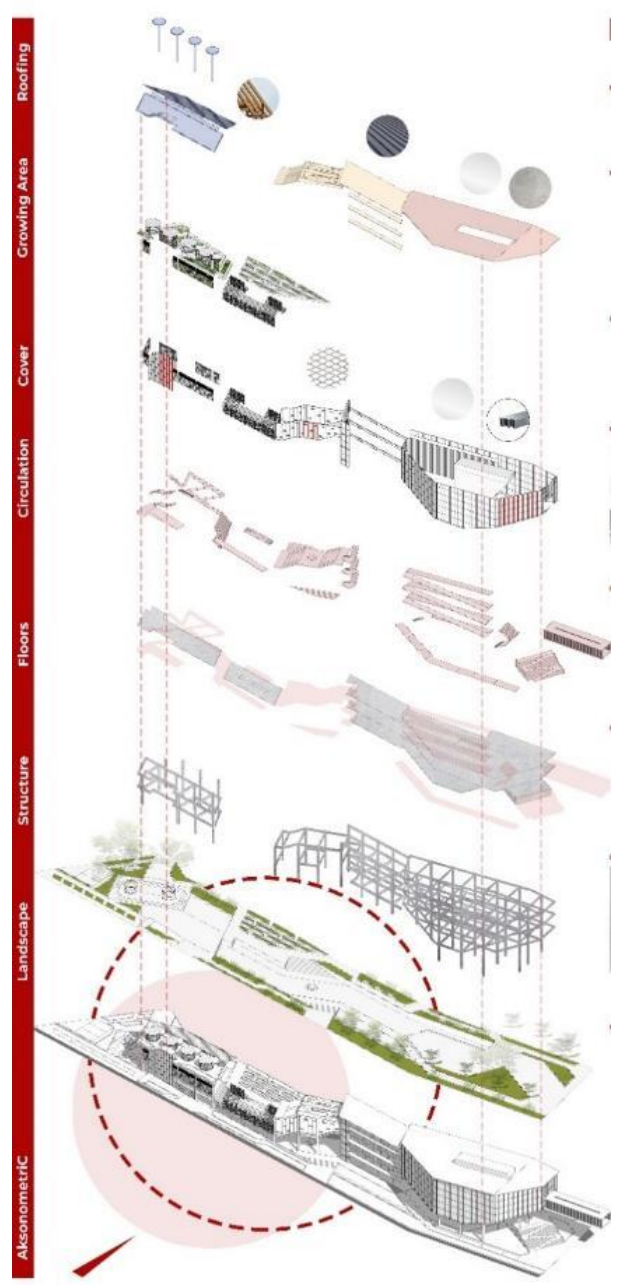

Gambar 8. Skema Elemen Bangunan Sumber: Penulis, 2020

\section{Pengairan dan Pemipaan}

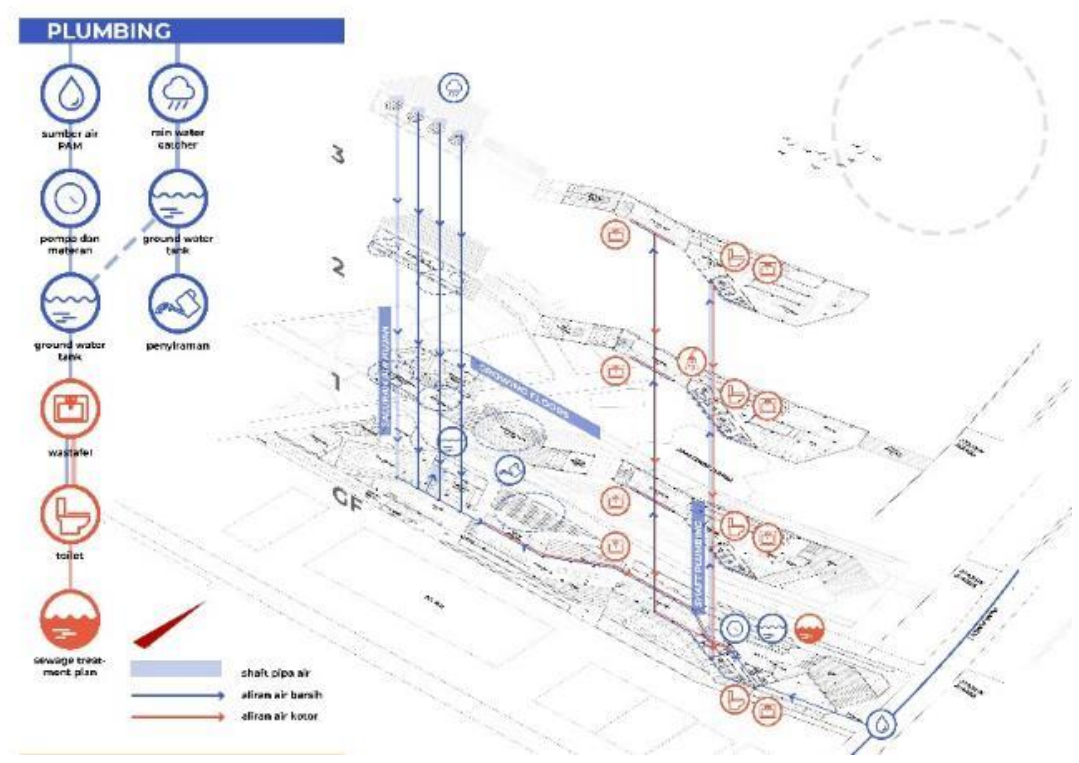

Gambar 9. Skema Pengairan dan Pemipaan

Sumber: Penulis, 2020 
Sumber air PAM masuk ke Ground Water Tank melalui meteran air, dipompa ke lantai tingkat melalui shaft untuk toilet dan wastafel. Air kotor pembuangan dialirkan ke Sewege Treatment Plan dan roil kota. Kemudian sumber air hujan alirkan dan ditampung dan didaur-ulang untuk penyiraman tanaman dan sayur, juga flush toilet.

\section{Elektrikal}

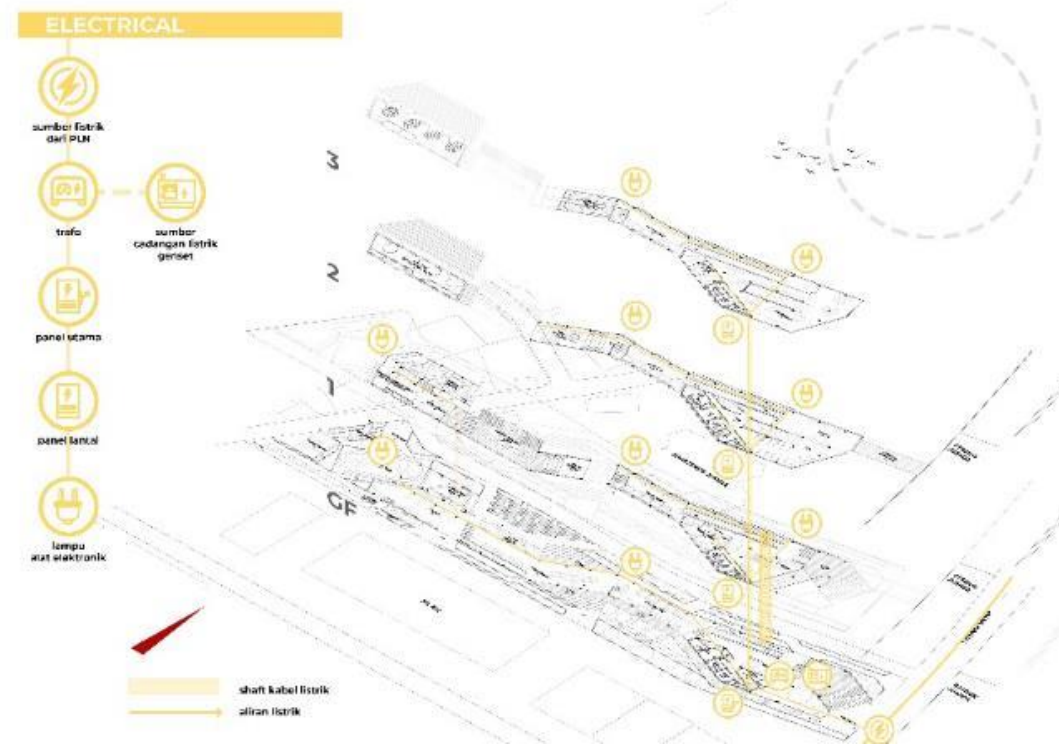

Gambar 10. Skema Elektrikal

Sumber: Penulis, 2020

Sumber listrik PLN masuk ke trafo bangunan yang terhubung paralel dengan sumber cadangan listrik genset kemudian menuju panel utama di lantai dasar, dialirkan ke panel lantai, lalu ke lampu dan alat elektronik lainnya.

Keadaan Darurat dan Kebakaran

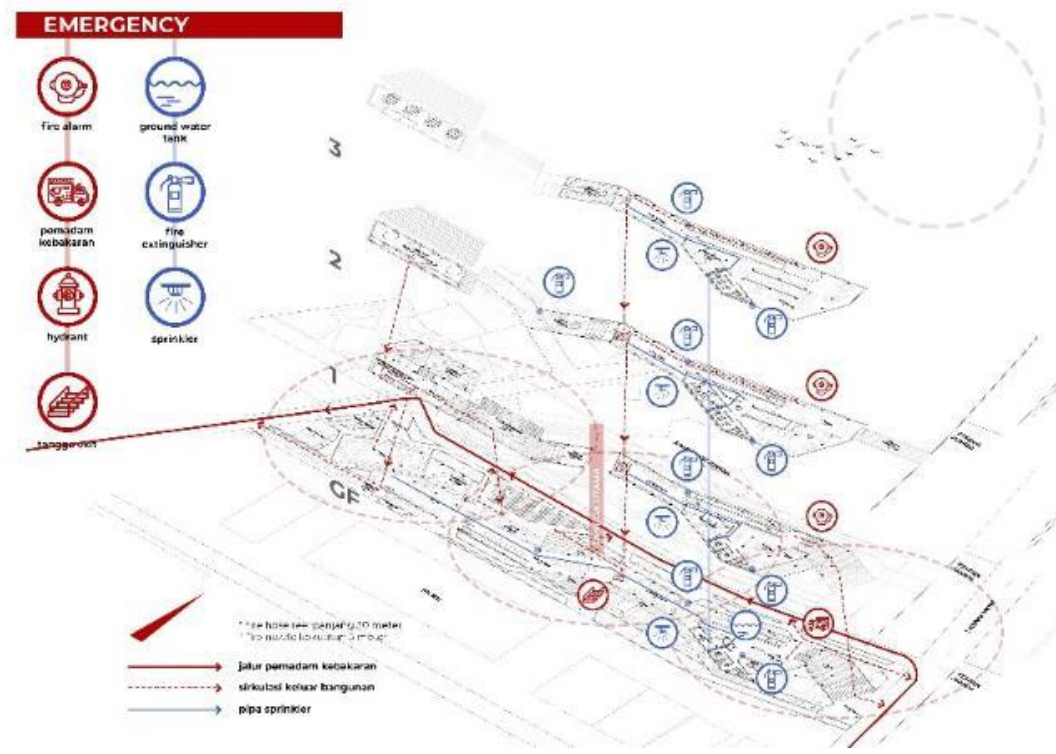

Gambar 11. Skema Keadaan Darurat Sumber: Penulis, 2020 
Peletakan fire alarm, fire extinguisher, sprinkler di setiap lantai. Untuk jalur pemadam kebakaran pada jalan sisi utara tapak dengan selang air mencapai 30 meter sehingga dapat mencapai setiap area bangunan. Jalan keluar darurat dengan menuruni tangga kemudian keluar tapak.

\section{Servis dan Pembuangan}

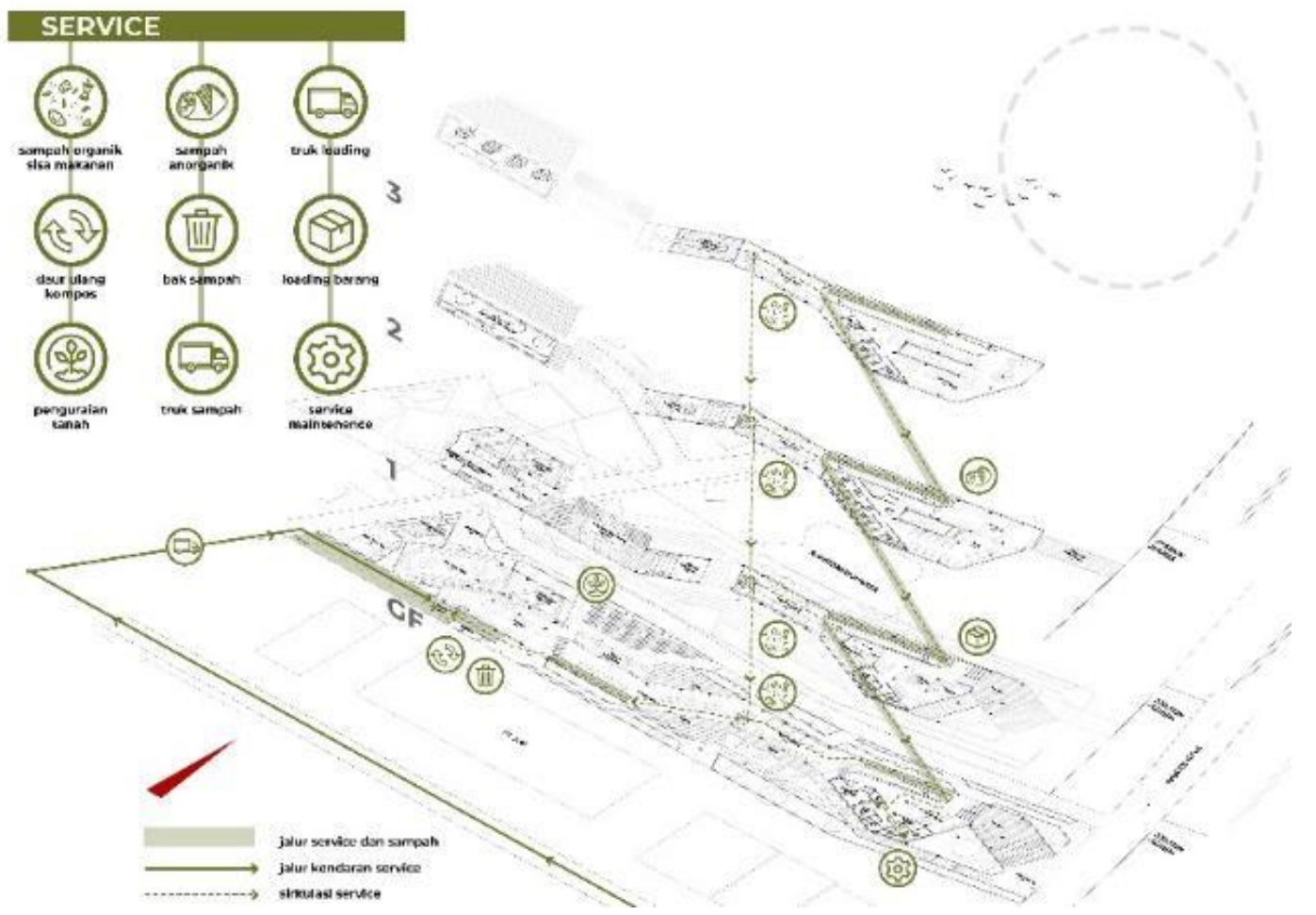

Gambar 12. Skema Servis dan Pembuangan Sumber: Penulis, 2020

Sampah makanan organik didaur-ulang menjadi kompos dan sampah anorganik dibuang ke bak sampah. Truk sampah atau loading barang melewati jalur belakang tapak, kemudan untuk loading barang berat melalui ram.

\section{KESIMPULAN}

Kehadiran Perhentian Kuliner Juanda atau Juanda Food Station sebagai third place menjadi pelebur masyarakat Kebon Kelapa dan komuter Stasiun Juanda. Program yang ditawarkan memberikan pengalaman baru dalam menikmati konsumsi sehari-hari. Dengan meningkatkan nilai suatu bahan makanan sehingga dapat dinikmati secara inklusif dari berbagai kalangan. Tapak di sekitar stasiun juga moda transportasi masal lain berpotensi jadi third place yang dapat menghubungkan komuter pendatang dengan warga lokal. Strategi yang dilakukan dengan mengangkat potensi yang ada pada kawasan tersebut mulai dari latar belakang sosial, ekonomi, sejarah, seni dan budaya. Dengan demikian jurnal perancangan ini diharapkan dapat mendorong penataan kota dalam meningkatkan kualitas perencanaan kota dengan menghadirkan ruang publik berupa third place.

\section{REFERENSI}

Armand, A. (2017). Arsitektur yang Lain. Jakarta: PT Gramedia Pustaka Utama.

Badan Pusat Statistik Provinsi DKI Jakarta. (2019). Provinsi DKI Jakarta Dalam Angka 2018. Jakarta: Badan Pusat Statistik Provinsi DKI Jakarta

Fujimoto, S. (2008) Primitive Future. Inax 
Jormakka, K. (2008). Basics Design Methods. Massachusetts: Birkhäuser Boston Norberg-Schulz, C. (1968). Intentions in Architecture. Massachusetts: The MIT Press.

Oldenburg, R. (1989). The Great Good Place. Massachusetts: Da Capo Press

Project for Public Spaces, diakses 20 Januari 2020, www.pps.org

Survei Business-to-Business (B2B) online expert 2016

The 2017 Global Least \& Most Stressful Cities Ranking. Retrieved February 10, 2020, from https://www.zipjet.co.uk/2017-stressful-cities-ranking.

Tschumi, B. (1994). Architecture and Disjunction. Massachusetts: The MIT Press.

United Nation. (2015). Transforming Our World: The 2030 Agenda for Sustainable Development. Retrieved February 17, 2020, from www.sustainabledevelopment.un.org Zumthor, P (1998) Thinking Architecture. Birkhauser 